\title{
Differential Expression of Copper-Zinc Superoxide Dismutase Gene of Polygonum sibiricum Leaves, Stems and Underground Stems, Subjected to High-Salt Stress
}

\author{
Chun-Pu Qu ${ }^{1}$, Zhi-Ru Xu ${ }^{2}$, Guan-Jun Liu ${ }^{1}{ }^{1}$, Chun Liu ${ }^{1}$, Yang Li ${ }^{1}$, Zhi-Gang Wei ${ }^{1}$ and \\ Gui-Feng Liu ${ }^{1}$
}

1 The Laboratory of Forest Genetics and Breeding and Biotechnology of Ministry of Education, Northeast Forestry University, 26 Hexing Road, Harbin 150040, China;

E-Mails: qcp0451@msn.com.cn (C.-P.Q.); liuchun314@yahoo.com.cn (C.L.);

liyangzaixian362@163.com (Y.L.); zhigangwe@163.com(Z.-G.W.); liuguifeng@126.com (G.-F.L.)

2 Life Science College, Northeast Forestry University, Harbin 150040, China;

E-Mail: xuzhiru2003@126.com

* Author to whom correspondence should be addressed; E-Mail: liuguanjun2010@msn.com.cn; Tel.: +86-451-82190607-13; Fax: +86-451-82190607-11.

Received: 30 September 2010; in revised form: 20 November 2010 / Accepted: 29 November 2010 / Published: 17 December 2010

\begin{abstract}
In aerobic organisms, protection against oxidative damage involves the combined action of highly specialized antioxidant enzymes, such as copper-zinc superoxide dismutase. In this work, a cDNA clone which encodes a copper-zinc superoxide dismutase gene, named $P S-C u Z n S O D$, has been identified from $P$. sibiricum Laxm. by the rapid amplification of cDNA ends method (RACE). Analysis of the nucleotide sequence reveals that the PS-CuZnSOD gene cDNA clone consists of $669 \mathrm{bp}$, containing $87 \mathrm{bp}$ in the 5' untranslated region; 459 bp in the open reading frame (ORF) encoding 152 amino acids; and $123 \mathrm{bp}$ in 3' untranslated region. The gene accession nucleotide sequence number in GenBank is GQ472846. Sequence analysis indicates that the protein, like most plant superoxide dismutases (SOD), includes two conserved ecCuZnSOD signatures that are from the amino acids 43 to 51, and from the amino acids 137 to 148 , and it has a signal peptide extension in the front of the $N$-terminus (1-16 aa). Expression analysis by real-time quantitative PCR reveals that the PS-CuZnSOD gene is expressed in leaves, stems and underground stems. $P S-C u Z n S O D$ gene expression can be induced by $3 \% \mathrm{NaHCO}_{3}$. The
\end{abstract}


different mRNA levels' expression of PS-CuZnSOD show the gene's different expression modes in leaves, stems and underground stems under the salinity-alkalinity stress.

Keywords: P. sibiricum Laxm.; PS-CuZnSOD; RACE; real-time PCR; gene expression

\section{Introduction}

Even when plants grow and develop under natural conditions, they are inevitably affected by environmental stresses due to their immobility [1]. This could lead to the production of a lot of reactive oxygen species (ROS), such as superoxide anion, hydrogen peroxide $\left(\mathrm{H}_{2} \mathrm{O}_{2}\right)$, hydroxyl radical and singlet oxygen, which are harmful to intercellular components such as DNA, protein and membrane lipids. High active oxygen species (AOS) levels initiate signaling responses that include enzyme activation, gene expression, cell apoptosis and cellular damage [2]. Organisms employ an antioxidant defense system to protect themselves against the toxic effects caused by such a signal. Superoxide dismutases (superoxide: superoxide oxidoreductase, EC 1.15.1.1; SOD) are the first line of defense against the oxidative stresses by catalyzing reactive oxygen molecules to hydrogen peroxide that is consequently converted to water by catalase [3].

Superoxide dismutases (SODs) are important antioxidant enzymes that occur in virtually all oxygenrespiring organisms [4]. SODs catalyze the dismutation of superoxide $\left(\mathrm{O}_{2}{ }^{-}\right)$into molecular oxygen $\left(\mathrm{O}_{2}\right)$ and $\mathrm{H}_{2} \mathrm{O}_{2}\left[2 \mathrm{O}_{2}^{-}+2 \mathrm{H}^{+} \rightarrow \mathrm{O}_{2}+\mathrm{H}_{2} \mathrm{O}_{2}\right]$. Four types of SODs have been identified. Copper-zinc superoxide dismutase: The most important enzyme of the oxygen scavenging enzymes [5,6], which is closely related to anti-aging and resistance to stress in plants [6-9]. Iron SOD has been found in prokaryotes, in algae and in some higher plant chloroplasts [10]; Manganese SOD is found in prokaryotes and mitochondria; and a fourth with the coupled Ni (II/III) at the active site (Ni-SOD), which is found in the Streptomyces genus [11]. Copper-zinc superoxide dismutase can be divided into two forms; one is in cytosolic and the other is in chloroplastic isoenzymes. Copper-zinc superoxide dismutase in cytosolic is found mainly in cases of induced adverse environment [12,13].

Superoxide dismutase (SOD) was first isolated from bovine red blood cells by Mann and Keilin in 1938. Until now, copper-zinc superoxide dismutase has been cloned in several species of plants including rice, corn, and others [13-21]. The transgenic plants with overexpression of $S O D$ gene in tobacco and alfalfa could resist cold stress, and markedly enhance antioxidant capacities [22-24].

Polygonum sibiricum Laxm. is a Dicotyledoneae Polygonaceae perennial herb. It grows in wetland, near the riverbank on saline and alkaline land. As one of the minority important halophytes grown in salinity-alkalinity areas, it is considered to be a promising species as a potential genetic resource of genetic transformation, and also can be employed as an experimental system for conducting research on salt resistance.

Salinity-alkalinity stress is one of the main abiotic stresses that restrict the development of agriculture worldwide. Compared to other abiotic salt stresses, there are limited studies on carbonate stress, though the main salt of soil, $\mathrm{NaHCO}_{3}$, has a severe effect on plants. The aim of the present study is to clone copper-zinc superoxide dismutase, which is located in the cytosolic in P. sibiricum Laxm., and to present the nucleotide sequence of copper-zinc superoxide dismutase, comparing its sequence 
with other known SODs from other species; and to evaluate this copper-zinc superoxide dismutase expression in leaves, stems and underground stems, when P. sibiricum Laxm. was induced under salinity-alkalinity stress. It is hoped to clarify the effects of $P S-C u Z n S O D$ in salinity-alkalinity resistance, forming a good basis for further study on the mechanisms of salinity-alkalinity stress tolerance in P. sibiricum Laxm.

\section{Results and Discussion}

\section{1. cDNA Cloning, Sequencing and Bioinformatics Analysis of PS-CuZnSOD}

In order to isolate cDNA encoding for copper-zinc superoxide dismutase, PCR reactions were performed using primers and total cDNA of plant leaves. Products of amplification were cloned and sequenced. Computer analysis, using the BLAST algorithm, confirmed that the selected sequence corresponded to a copper-zinc superoxide dismutase. The full-length copper-zinc superoxide dismutase cDNA fragment of $P$. sibiricum Laxm. was obtained by overlapping two cDNA fragments. The full-length copper-zinc superoxide dismutase cDNA comprised of $669 \mathrm{bp}$, containing $87 \mathrm{bp}$ in the 5'-untranslated region (UTR); $459 \mathrm{bp}$ in the open reading frame (ORF); and $123 \mathrm{bp}$ in 3'-UTR without poly (A) tail (Figure 1). The ORF encodes a polypeptide of 152 amino acids. The calculated molecular mass of the mature protein (152 amino acids) is $15.3 \mathrm{kDa}$, with an estimated $\mathrm{p} I$ of 5.7 . Two conserved CuZnSOD signatures are from the amino acids 43 to 51 , and from the amino acids 137 to 148 . The cDNA sequence and deduced amino acid sequence has been submitted to the NCBI GenBank as accession number GQ472846. Two cysteines (Cys56 and Cys145) form a disulfide bond for this gene.

Figure 1. Nucleotide and deduce amino acid sequences of $P S-C u Z n S O D$ cDNA from $P$. sibiricum Laxm. The PCR products of PS-CuZnSOD cDNA were sequenced. The full length was $669 \mathrm{bp}$, with a 5' untranslated region of $87 \mathrm{bp}$, a 3' untranslated region of $123 \mathrm{bp}$ and an open reading frame (ORF) encoding 152 amino acid (459 bp). The cDNA sequence of PS-CuZnSOD has been submitted to GenBank (accession No. GQ472846). The rectangle indicates the active site of the $P S-C u Z n S O D$; ellipse indicates the $\mathrm{Cu}^{2+}$ binding site; * indicates the $\mathrm{Zn}^{2+}$ binding site; \# indicates the stop codon. Two conserved CuZnSOD signatures are shown in broken line. The signal peptide is shown in solid line. Two cysteines (Cys56 and Cys145) form a disulfide bond for this gene.

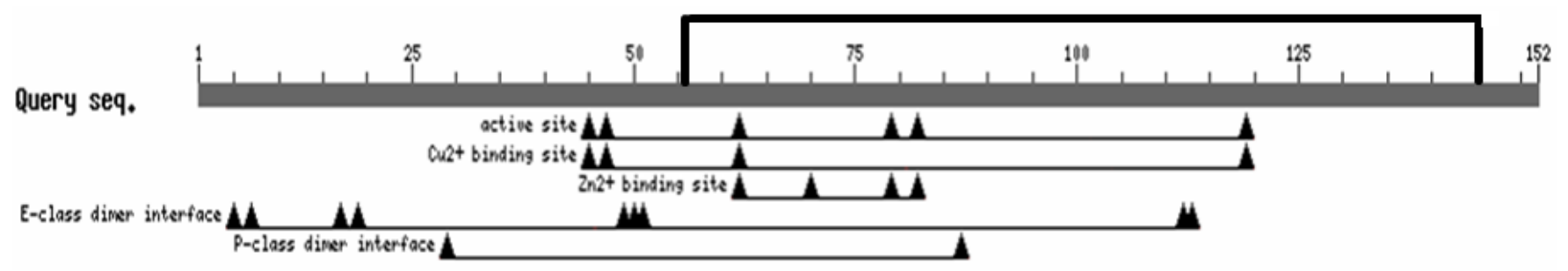


Figure 1. Cont.

1 ATT CAC CTC TCA ACA ACC CTT CAC TCT ATA ATC TTC TAC TTC CAT 45

46 CTC TCT CTT ACA ACA AGG GGT TCC CTG AGA TCA CAG GTG AAA ATG 90

1 M 1

91 GTA AAG GCT GTG GTT GTT CTC AAC AGC AGT GCG GGA GTT AGT GGA 135

$\begin{array}{llllllllllllllllll}2 & \text { V } & \text { K } & \text { A } & \text { V } & \text { V } & \text { V } & \text { L } & \text { N } & \text { S } & \text { S } & \text { A } & \text { G } & \text { V } & \text { S } & \text { G } & 16\end{array}$

136 ACT GTC CAC TTC TCC CAA GAA GGA GAT GGT CCA ACA ACC GTC ATA 180

$\begin{array}{lllllllllllllllll}17 & \text { T } & \text { V } & \text { H } & \text { F } & \text { S } & \text { Q } & \text { E } & \text { G } & \text { D } & \text { G } & \text { P } & \text { T } & \text { T } & \text { V } & \text { I } & 31\end{array}$

181 GGG AAT CTC TCT GGT CTT AAG CCT GGG CTT CAT GGT TTC CAT GTT 225

$\begin{array}{lllllllllllllllll}32 & G & \text { N } & \text { L } & \text { S } & \text { G } & \text { L } & \text { K } & \text { P } & \text { G } & \text { L } & \text { H } & \text { G } & \text { F } & \text { H } & \text { V } & 46\end{array}$

226 CAT GCT CTT GGG GAC ACA ACT AAT GGT TGC ATG TCT ACT GGA $\ddot{\text { CCA }} 270$

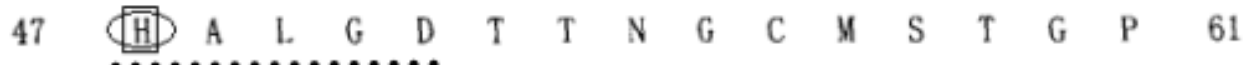

$271 \ddot{C A C} \dddot{T T C} \ddot{A} \ddot{A C} \ddot{C} \ddot{C T}$ GCT GGA AAA GAG CAT GGT GCT CCA GAA GAC GAG 315

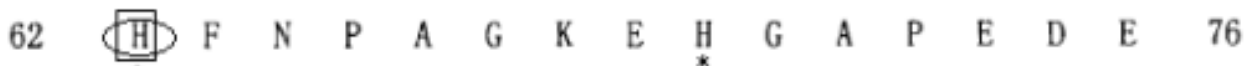

316 CÁT CGT CAT GCT GGT GAT CTG GGA AAT GTA ACA GTT GGT GAT GAT 360

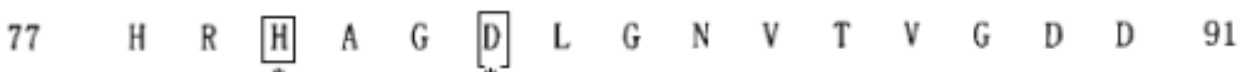

361 GGT ACT GCंT ACA TTC ACA ATC ATT GAT AAT CAG ATT CCT CTT GAT 405

$\begin{array}{lllllllllllllllll}92 & \text { G } & \text { T } & \text { A } & \text { T } & \text { F } & \text { T } & \text { I } & \text { I } & \text { D } & \text { N } & \text { Q } & \text { I } & \text { P } & \text { L } & \text { D } & 106\end{array}$

406 GGA CCA AAT TCC ATT ATC GGA AGG GCT GTT GTT GTT CAT GCT GAT 450

$\begin{array}{llllllllllllllllllllll}107 & G & P & N & \text { S } & \text { I } & \text { I } & G & \text { R } & \text { A } & \text { V } & \text { V } & \text { V } & \text { A } & \text { D } & 121\end{array}$

451 CCT GAT GAT CTT GGA AAG GGC GGA CAC GAG CTC AGC AAG AGC ACT 495

$\begin{array}{lllllllllllllllll}122 & \text { P } & \text { D } & \text { D } & \text { L } & \text { G } & \text { K } & \text { G } & \text { G } & \text { H } & \text { E } & \text { L } & \text { S } & \text { K } & \text { S } & \text { T } & 136\end{array}$

496 GGA AAT GCT GGT GGA AGA ATC GCC TGT GGT ATC ATT GGC CGT CAA 540

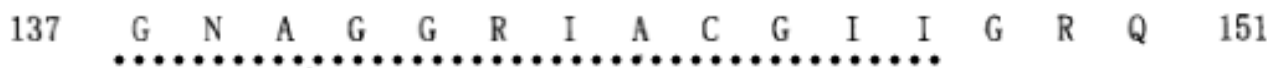

541 GGT TAA ACT GCA TGT AGT TGT GCT TGG GGT GCT CTT GAT GGT GAT 585

152 G \# 152

586 CTT AAT AAG TAT TGA AAT TGG CTG TAA TCT TTA TTT TTG TCT CAA 630

631 AAT TCC AAG ACT TGT CTT GGT TTG TCT GGT TTT GTT CAA 669

\subsection{Homology Comparison of PS-CuZnSOD}

The comparison of the ORFs with other known SODs indicates that the PS-CuZnSOD shows homology: Identities = 125/136 (92\%); with Melastoma malabathricum: Identities = 121/136 (89\%); with Mesembryanthemum crystallinum: Identities $=122 / 147$ (83\%); with Fagus sylvatica: Identities = 122/136 (90\%); with Populus suaveolens: Identities = 123/136 (91\%); with Gossypium hirsutum: Identities = 122/136 (90\%); with Codonopsis lanceolata : Identities = 120/136 (89\%); with Ricinus communis: Identities = 117/136 (87\%); with Litchi chinensis: Identities = 117/136 (87\%); with Citrus limon and so it continues. PS-CuZnSOD was genetically distinct from other kinds of SOD (Figure 2). A phylogenetic tree based on evolutionary distances was constructed from amino acid sequences using the njplotWIN95 program (Figure 3). All of the bioinformatics analysis results suggested that $P$. sibiricum Laxm. SOD should be a plant cytoplasm copper-zinc superoxide dismutase. 


\subsection{Tissue Expression of PS-CuZnSOD}

Copper-zinc superoxide dismutase expressed in each organ of $P$. sibiricum Laxm. is shown in Figure 4. In a RT-PCR study, specific primers (SOD-F: 5'-AGTGCGGGAGTTAGTGG-3' and SOD-R: 5'-CGATGCTCGTCTTCTGG-3') were used to amplify a 203 bp fragment with cDNA from leaves, stems and underground stems, organs using $18 \mathrm{~S}$ as a positive control. The RT-PCR showed that the CuZnSOD was detected in leaves, stems and underground stems. In leaves, the increase of the copper-zinc superoxide dismutase mRNA expression level reached its peak in 24 hours after $3 \%$ $\mathrm{NaHCO}_{3}$ stress, and gradually decreased (Figure 4B). In stems, the increase of the copper-zinc superoxide dismutase mRNA expression reached its peak in 72 hours after salinity-alkalinity stress (Figure 4C). That is, in leaves and stems they were up-regulated and then down-regulated during 3\% $\mathrm{NaHCO}_{3}$ stress. Contrastingly, the copper-zinc superoxide dismutase transcripts were fluctuated and down-regulated after $3 \% \mathrm{NaHCO}_{3}$ stress in underground stems' organs (Figure 4D).

Figure 4. The change of $P S-C u Z n S O D$ after $3 \% \mathrm{NaHCO}_{3}$ exposure in leaves, stems, underground stems' organs. Total RNA was prepared using SDS reagent for all $P$. sibiricum Laxm. samples taken at $0,4,8,24,48,72,144$ h, independent of $3 \% \mathrm{NaHCO}_{3}$ stress condition. After digested with DNase I to eliminate the genome contamination, the cDNA was synthesized using the oligo $d(T)$ primer and random 6 primer. Real-time PCR was performed with the DNA Engine Opticon ${ }^{\mathrm{TM}}$-II sequence detection system. SYBR green Real-time PCR mix (TaKaRa) was used for PCR. (A) The expression of $P S-C u Z n S O D$ gene in leaves, stems, underground stems' organ without stress comparison; (B) The levels of PS-CuZnSOD mRNA in leaves tissues; (C) The level of PS-CuZnSOD mRNA in stems tissues; (D) The levels of PS-CuZnSOD mRNA in underground stems tissues. A multiple comparisons test was conducted to compare significant differences in $P S$-CUZnSOD expression between leaves, stems and underground stems using the SPSS software. A significant level of $p=0.05$ was chosen.
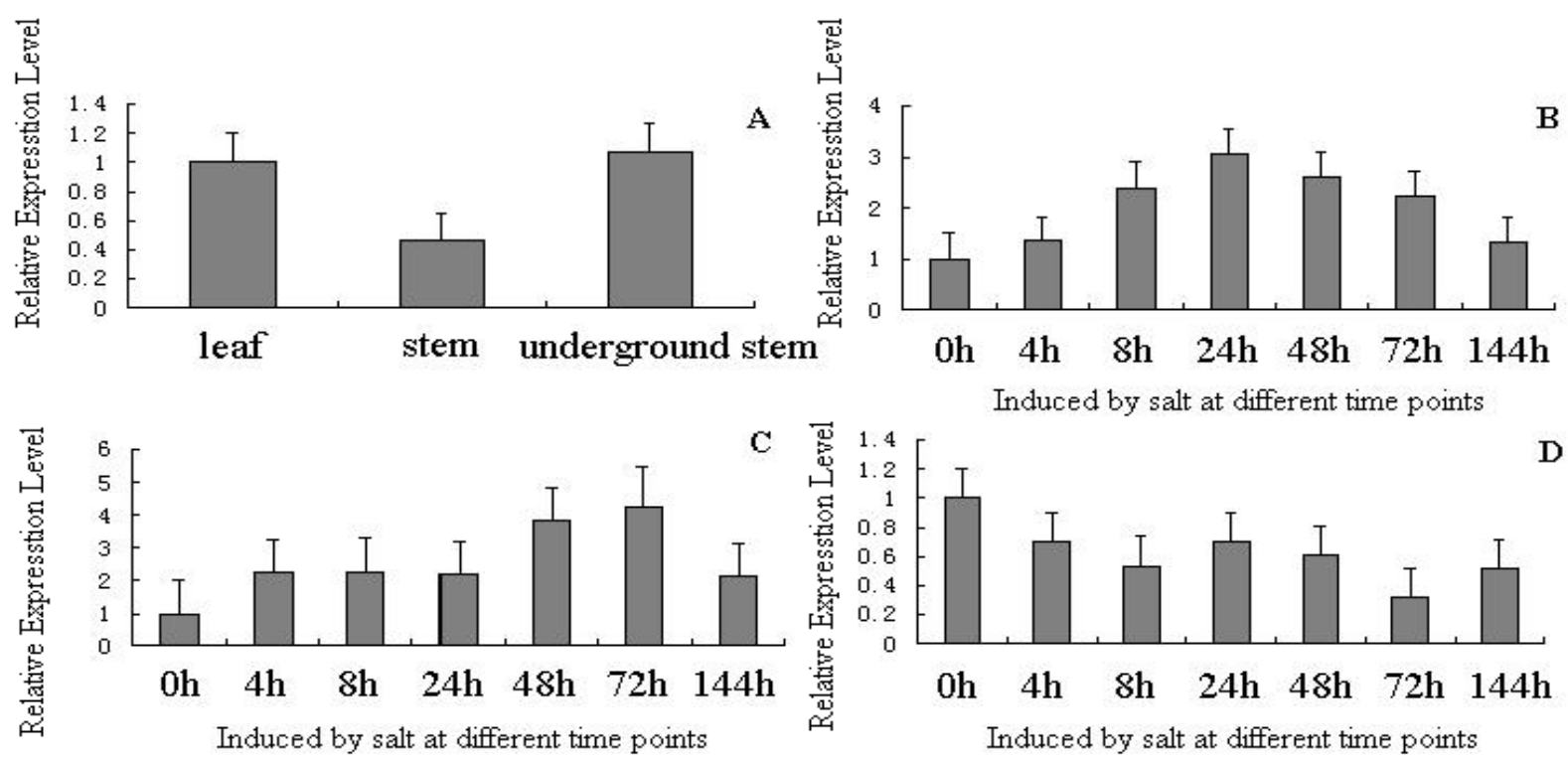
Tissue distribution of $P S-C u Z n S O D$ mRNA was ubiquitous in all the tissues examined in this study, which is not surprising since the expression of copper-zinc superoxide dismutase in a wide range of cell types has already been found previously. Based on experimental exposures to $3 \% \mathrm{NaHCO}_{3}$, P. sibiricum Laxm. SOD mRNA was apparently affected by the durations of $3 \% \mathrm{NaHCO}_{3}$ stress. mRNA expression of $P S-C u Z n S O D$ was durations-dependent in general; the saturation of expression (reaching maximum level) was observed in stems at $72 \mathrm{~h}$ based on the RT-PCR. There were some different responses of $\mathrm{PS}-\mathrm{CuZnSOD}$ to $3 \% \mathrm{NaHCO}_{3}$ exposure in every organ (or tissue) from our data. We deduce that tuning expression of copper-zinc superoxide dismutase mRNA may be used to change copper-zinc superoxide dismutase activity and in turn modulate plant growth under the salinity-alkalinity stress. The different expression mode of copper-zinc superoxide dismutase in leaves, stems and underground stems might be the reason $P$. sibiricum Laxm. has higher efficiency and economy in antioxidant and resistance to stress in plants. However, the specific factors underlying the regulatory mechanism have not been clearly understood. Our results may provide the basis for future investigations of copper-zinc superoxide dismutase roles in salinity-alkalinity stress development in different organs.

\section{Experimental Section}

\subsection{Plant}

P. sibricum Laxm. plants (plant height $10-15 \mathrm{~cm}$ ) were obtained from salinity-alkalinity fields in Zhaodong, Heilongjiang ( $\mathrm{pH}=8.68$ ). As the underground stems of $P$. sibiricum Laxm. are used for experimental materials, the experiments of rapid propagation have been carried out and the materials are grown in phytotron at $24{ }^{\circ} \mathrm{C}$. The samples were treated at different stages using $3 \% \mathrm{NaHCO}_{3}$. A total of 210 plants (plant height 10-15 cm) were allotted into seven treatments randomly: i.e., $0 \mathrm{~h}$ (blank), 4 h, 8 h, 24 h, 48 h, $72 \mathrm{~h}$ and 144 h. Each treatment consists of six replicates with five plants of $P$. sibricum Laxm. each. After being harvested, all samples were immediately preserved in liquid nitrogen and kept at $-80{ }^{\circ} \mathrm{C}$ until they were used for isolating the RNA.

\subsection{RNA Isolation from P. sibiricum Laxm. and Reverse Transcription (RT)}

Total RNA was extracted using a phenol sodium dodecyl sulfate extraction/LiCl precipitation procedure [25].

\subsection{Obtaining 3' and 5' Regions by RACE}

To isolate the complete 5' and 3' regions of this gene, the rapid amplification of cDNA ends (RACE) method was used. First-strand cDNA synthesis was performed using Smart ${ }^{\mathrm{TM}}$ RACE cDNA amplification kit (Clontech). Previously we obtained the PS-CuZnSOD 3' EST sequences from the P. sibiricum Laxm. cDNA Library [26]. According to the EST, two specific primers were designed on the basis of the SOD 3'UTR for 5'-RACE. SODZnN: 3'-AGAACCAAACAGACCAAAACAAG-5', SODZn: 3'-CTCATAACATAAGGAAAGAAAGGG-5'. The 5' fragment PCR was then carried out according to the manufacturer's instructions (Clontech Kit). Next, the fragments were cloned and 
sequenced. A pair of specific primers was designed to amplify the ORF of PS-CuZnSOD gene (SOD-A: 5'-GATTACAGCCAATTTCAATAC-3', SOD-S: 5'-CTCTTACAACAAGGGGTTC-3').

\subsection{Subcloning}

The PCR fragments were subjected to electrophoresis on $0.8 \%$ agarose gel for length differentiation, and amplified cDNA fragments were cloned into the pGEM-T Easy vector following the instructions provided (Promega, Madison, WI, U.S.). Recombinant bacteria were identified by blue/white screening and confirmed by PCR. Plasmids containing the insert were purified (Promega minipreps) and used as a template for DNA sequencing.

\subsection{Nucleotide Sequence Analysis}

The fragments were linked by the soft Bio-Edit CAP contig assembly program. The PS-CuZnSOD gene sequence was analyzed and compared using the BLAST P and ORF search programs with GenBank database search. The multiple sequence alignment of $P S-C u Z n S O$ gene was created by Clustal W analysis program, signal-peptide site was predicted by Signal P3.0, the SOD protein MW and $\mathrm{p} I$ were computed by ProtParam [27], and disulfide connectivity was predicted by SCRATCH Protein Predictor [28].

\subsection{Quantification of PS-CuZnSOD Gene Expression by Real-Time RT-PCR}

Total RNAs were isolated by SDS method from different tissues including stems, underground stems and leaves, at different handling stages induced by $3 \% \mathrm{NaHCO}_{3}$, treat at $0 \mathrm{~h}$ (blank), $4 \mathrm{~h}, 8 \mathrm{~h}$, $24 \mathrm{~h}, 48 \mathrm{~h}, 72 \mathrm{~h}$ and $144 \mathrm{~h}$. The residue of DNA were removed by DNase I digesting, at $37{ }^{\circ} \mathrm{C}$ for $30 \mathrm{~min} .4$ microgram of the total RNA were used in each lane and electrophoresed in a $0.8 \%$ agarose gel, at $100 \mathrm{~V} / 12 \mathrm{~cm}$ for $15 \mathrm{~min}$. First-strand cDNA synthesis was performed using M-MLV reverse transcriptase (TaKaRa Biotechnology (Dalian) Co., Ltd. Japan) to transcribe poly $(\mathrm{A})^{+}$RNA with oligo-d(T)18 and random six as the primers, reaction conditions were recommended by the manufacturer's instructions. The cDNA was used for the assay of quantitative real-time PCR. The SYBR Green I real-time RT-PCR assay was carried out in an Option-II Sequence Detection System (MJ Research, U.S.). The amplifications were performed in a 96-well plate in a $25 \mu \mathrm{L}$ reaction volume containing $12.5 \mu \mathrm{L}$ of $2 \times$ SYBR Green Master Mix (TARAKA), $2.5 \mu \mathrm{L}$ (each) SOD-F and SOD-R primers $(10 \mathrm{mM}), 1 \mu \mathrm{L}$ of template, and $9 \mu \mathrm{L}$ of DEPC-water. The thermal profile for SYBR Green real-time PCR was $95{ }^{\circ} \mathrm{C}$ for $2 \mathrm{~min}$, followed by 45 cycles of $95{ }^{\circ} \mathrm{C}$ for $15 \mathrm{~s}$ and $60{ }^{\circ} \mathrm{C}$ for $30 \mathrm{~s}$. In a 96-well plate, each sample was conducted in triplicate. DEPC-water for the replacement of template was used as negative control. The relative expression was calculated as $2^{-\Delta \Delta C t} ; C t$ : cycle threshold.

\subsection{Statistical Analysis}

A multiple comparisons (Duncan's) test was conducted to compare significant differences in $P S-C u Z n S O D$ expression between leaves, stems and underground stems, using the SPSS software. A significant level of $p=0.05$ was chosen. 


\section{Conclusions}

In plants, several enzymes like SODs are involved in the release of AOSs. It is known that SOD catalyzes the rapid two-step dismutation of the toxic superoxide anion to molecular oxygen and hydrogen peroxide, through alternating reduction and oxidation of the active-site metal ion [29]. SODs play an important role in antioxidant defense pathways in response to oxidative stress [10]. In this work, the full length of a $P S-C u Z n S O D$ gene was isolated from $P$. sibiricum Laxm. by the rapid amplification of cDNA ends method. Analysis of the nucleotide sequence revealed that the $P S-C u Z n S O D$ gene cDNA clone consists of $669 \mathrm{bp}$, containing $87 \mathrm{bp}$ in the 5' untranslated region; $459 \mathrm{bp}$ in the open reading frame (ORF) encoding 152 amino acids; and $123 \mathrm{bp}$ in the 3' untranslated region. The gene accession nucleotide sequence number in GenBank was GQ472846. Sequence analysis indicates that the protein, like in most others plants, CuZnSOD, includes two conserved domains from amino acid 43 to 51 and from amino acid 137 to148, which catalyzes the dismutation of superoxide $\left(\mathrm{O}_{2}{ }^{-}\right)$into molecular oxygen $\left(\mathrm{O}_{2}\right)$ and $\mathrm{H}_{2} \mathrm{O}_{2}$. Two cysteines (Cys56 and Cys 145) form a disulfide bond for this gene. $P S-C u Z n S O D$ has a signal peptide extension in the front of the $N$-terminus (1-16 aa), which is markedly different compared to other plants intracellular CuZnSODs.

Expression analysis by real-time quantitative PCR revealed that $P S-C u Z n S O D$ gene is expressed in leaves, stems and underground stems. In leaves and stems it was up-regulated and then down-regulated during $3 \% \mathrm{NaHCO}_{3}$ stress. On the contrary, the copper-zinc superoxide dismutase transcripts fluctuated and were down-regulated after $3 \% \mathrm{NaHCO}_{3}$ stress in underground stem organs. That is, under $3 \% \mathrm{NaHCO}_{3}$ stress, $P S-C u Z n S O D$ gene expression can be induced differently. It indicates that there are different express modes in leaves, stems and underground stems. We presume that $P S-C u Z n S O D$ genes in leaves and stems play important roles in the process of induction by salinity-alkalinity resistance, and the down-regulation of $P S-C u Z n S O D$ genes may be related to the effects of $\mathrm{H}_{2} \mathrm{O}_{2}$-products of $P S-C u Z n S O D$. Additionally, it seems that the PS-CuZnSOD gene does not function in salinity-alkalinity resistance in underground stem organs. Currently, we do not know the exact role $P S-C U Z n S O D$ genes play in $P$. sibiricum Laxm. resistance to salinity-alkalinity stress. However, differential mRNA expression of some genes in P. sibiricum Laxm. seems to be either "protective" or cause "division of labor" [30-34]. So far, no reports have been shown that $P S-C u Z n S O D$ genes are differentially expressed during the salinity-alkalinity stress processes. We propose that the $P S-C u Z n S O D$ "division of labor" in different organs may play an important role in $P$. sibiricum Laxm. resistance to salinity-alkalinity stress. Our results may provide the basis for future investigations of $P S-C u Z n S O D$ roles in P. sibiricum Laxm. resistance to salinity-alkalinity stress.

\section{Acknowledgements}

This research was funded by the Key Project of Chinese Ministry of Education (No. 109054).

\section{References}

1. Li, B.; Wei, J.M.; Wei, X.L.; Tang, K.; Liang, Y.L.; Shu, K.X.; Wang, B.C. Effect of sound wave stress on antioxidant enzyme activities and lipid peroxidation of Dendrobium candidum. Colloids Surf. B 2008, 63, 269-275. 
2. Mackerness, S.A.H.; Fred, J.C.; Jordan, B.; Thomas, B. Early signaling components in ultraviolet-B responses: distinct roles for different reactive oxygen species and nitric oxide. FEBS Lett. 2001, 489, 237-242.

3. Den, H.G.J.; Haenen, G.R.; Vegt, E.; Vander, V.W.J.; Bast, A. Superoxide dismutase: the balance between prevention and induction of oxidative damage. Chem. Biol. Interact. 2003, 145, 33-39.

4. Scandalios, J.G. Oxidative Stress and the Molecular Biology of Antioxidant Defenses; Cold Spring Harbor Laboratory Press: Cold Spring Harbor, NY, USA, 1997; pp. 2-11.

5. Wang, R.G.; Chen, S.L.; Liu, L.Y.; Hao, Z.Y.; Weng, H.J.; Li, H.; Yang, S.; Duan, S. Genotypic differences in antioxidative ability and salt tolerance of three poplars under salt stress. J. Beijing For. Univ. 2005, 27, 46-52.

6. Song, F.N.; Yang, C.P.; Liu, X.M.; Li, G.B. Effect of salt stress on activity of superoxide dismutase(SOD) in Ulmus pumila L. J. For. Res. 2006, 17, 13-16.

7. Zhang, Y.; Luo, X.F.; Sheng, Y.B. Dynamic changes of anti-oxidation system in new cultvars of Rabinia pseudoacacia undergradual drought stress of soil. J. Zhejiang For. Inst. 2005, 22, 166-169.

8. Feng, C.J.; Luo, X.Y.; Sha, W.; Wang, F.G. Effect of low temperature stress on SOD, POD activity and proline content of alfalfa. Pratacultural Sci. 2005, 22, 29-32.

9. Guo, L.H.; Wu, X.L.; Gong, M. Roles of glutathione reductase and superoxide dismutase in heatshock-induced cross adaptation in maize seedlings. Plant Physiol. Commun. 2005, 41, 429-432.

10. Fridovich, I. Superoxide radical and superoxide dismutases. Annu. Rev. Biochem. 1995, 64, 97-112.

11. Choudhury, S.B.; Lee, J.W.; Davidson, G.; Yim, Y.I.; Bose, K.; Sharma, M.L.; Kang, S.; Cabelli, D.E.; Maroney, M.J. Examination of the Nickel Site Structure and Reaction Mechanism in Streptomyces seoulensis Superoxide Dismutase. Biochemistry 1999, 38, 3744-3752.

12. Rafael, P.T.; Estra, G. The tomato $\mathrm{Cu} / \mathrm{Zn}$ SOD superoxide dismutase genes are developmentally regulated and respond to light and stress. Plant Mol. Biol. 1991, 17, 745-760.

13. Sheri, P.K.; John, G.S. A comparison of the structure and function of the highly homologous maize antioxidant $\mathrm{Cu} / \mathrm{Zn}$ superoxide dismutase genes, sod4 and sod4A. Genetics 1996, 144, 317-328.

14. Sumio, K.; Kozi, A. Characteristic of amino acid sequences of chloroplast and cytoplasm isozymes of $\mathrm{Cu} / \mathrm{Zn}$ superoxide dismutase in spinach, rice and horsetail. Plant Cell Physiol. 1990, $31,99-112$.

15. Lin, C.T.; Lin, M.T.; Chen, Y.T.; Shaw, J.F. The gene structure of Cu/Zn-superoxide dismutase from sweet potato. Plant Physiol. 1995, 108, 827-828.

16. Bag, F.; Giannino, D.; Caparrini, S.; Carnussi, A.; Mariotti, D.; Racchi, M.L. Molecular cloning, characterization and expression of a manganese superoxide dismutase gene from peach (Prunus persica [L.] Batsch). Mol. Genet. Genomics 2002, 267, 321-328.

17. Hironori, K.; Shigeto, M.; Hideki, Y.; Takehiro, M.; Kunisuke, T. Molecular cloning and characterization of a cDNA for plastidic copper/zinc superoxide dismutase in rice (Oryza sativa L.). Plant Cell Physiol. 1997, 38, 65-69. 
18. Atsushi, S.; Hiroyuki, O.; Kunisuke, T. Nucleotide sequences of two cDNA clones encoding different $\mathrm{Cu} / \mathrm{Zn}$-superoxide dismutases expressed in developing rice seed (Oryza sativa L.). Plant Mol. Biol. 1992, 19, 323-327.

19. Lee, H.S.; Kim, K.Y.; You, S.H.; Kwon, S.Y.; Kwak, S.S. Molecular characterization and expression of a cDNA encoding copper zinc superoxide dismutase from cultured cells of cassava (Manihot esculenta Crantz). Mol. Genet. Genomics 1999, 262, 807-814.

20. Rafael, P.T.; Benedetta, N.; Dvora, A.; Elisha, P.Z.; Esra, G. Isolation of two cDNA clones from tomato containing two different superoxide dismutase sequences. Plant Mol. Biol. 1988, 11, 609-623.

21. Ronald, E.C.; Joseph, A.W.; John, G.S. Cloning of cDNA for maize superoxide dismutase2 (SOD2). Proc. Natl. Acad. Sci. USA 1987, 84, 179-183.

22. Bryan, D.M.; Chen, Y.R.; Mitchel, D.B.; Stephen, R.B.; Chris, B.; Dirk, I.; Kathleen, D.H.; Johan, B. Superoxide dismutase enhances tolerance of freezing stress in transgenic alfalfa (Medicago sativa L.) Plant Physiol. 1993, 103, 1155-1163.

23. Bryan, D.M.; Julia, M.; Kim, S.J. Iron-superoxide dismutase expression in transgenic alfalfa increases winter survival without a detectable increase in photosynthetic oxidative stress tolerance. Plant Physiol. 2000, 122, 1427-1437.

24. Wim, V.C.; Katelijne, C.; Marc, V.M.; Dirk, I.; Luit, S. Enhancement of Oxidative Stress Tolerance in Transgenic Tobacco Plants Overproducing Fe-Superoxide Dismutase in Chloroplasts. Plant Physiol. 1996, 112, 1703-1714.

25. Davis, K.R.; Schott, E.; Ausubel, F.M. Virulence of selected phytopathogenic pseudomonads in Arabidopsis thaliana. Mol. Plant-Microbe Interact. 1991, 4, 477-488.

26. Liu, G.J.; Liu, M.K.; Xu, Z.R.; Yan, X.F.; Zhu, X.; Yang, C.P. Construction and Preliminary Analysis of Six Period Mixed Leaves cDNA Library of $P$. sibiricum Laxm. under Salt Stress. Plant Physiol. Commun. 2008, 12, 1099-1105.

27. ProtParam Tool. Swiss Insitutude of Bioinformatics. Available online: http://au.expasy.org/tools/ protparam.html (accessed on December 17, 2010).

28. Cheng, J.; Randall, A.Z.; Sweredoski, M.J.; Baldi, P. SCRATCH: a protein structure and structural feature prediction server. Nucleic Acids Res. 2005, 33, W72-W76. Available online: http://www.ics.uci.edu/ baldig/scratch/ (accessed on 17 December 2010).

29. Mattia, F.; Peter, O.N.; Maria, E.S.; Alessandro, D. Superoxide dismutase kinetics. Methods Enzymol. 2002, 349, 38-49.

30. Li, Y.; Liu, G.J.; Qu, C.P.; Yang, C.X.; Wei, Z.G.; Liu, G.F.; Yang, C.P. Cloning of PsLEA Gene from $P$. sibiricum Laxm. and its Expression under $\mathrm{NaHCO}_{3}$ Stress. Mol. Plant Breed. 2010, 8, 276-282.

31. Liu, G.J.; Yang, C.X.; Qu, C.P.; Li, X.Z.; Liu, C.C.; Liu, G.F.; Yang, C.P. Cloning and Expression Analysis of Polygalacturonase Inhibiting Proteins Gene from P. sibiricum Laxm. Chin. J. Biochem. Mol. Biol. 2009, 25, 242-249.

32. Liu, G.J.; Tian, X.; Liu, C.C.; Qu, C.P.; Liu, G.F.; Yang, C.P. Cloning of Coding Sequence of Non-specific Transfer Protein from P. sibiricum Laxm. and Expression under Salinity Stress. Chin. J. Biochem. Mol. Biol. 2008, 24, 1140-1145. 
33. Liu, C.; Liu, G.J.; Qu, C.P.; Wei, Z.G.; Liu, G.F.; Yang, C.P. Cloning of CaM Gene from P. sibiricum Laxm. and Its Expression under Salt Stress. Plant Physiol. Commun. 2010, 46, 113-119.

34. Liu, G.J.; Qu, C.P.; Liu, M.K.; Wei, Z.G.; Liu, G.F.; Yang, C.P. Real-time PCR Analysis of Copper Chaperone Protein Gene Expression in P. sibiricum Laxm. Under Salt Stress. Chin. J. Biochem. Mol. Biol. 2008, 24, 1034-1039.

(C) 2010 by the authors; licensee MDPI, Basel, Switzerland. This article is an open access article distributed under the terms and conditions of the Creative Commons Attribution license (http://creativecommons.org/licenses/by/3.0/). 